\title{
Maternal and child health from a human rights perspective: the Indian scenario and nuns as community health enablers
}

\author{
Tomi Thomas $^{a}$, Anto Maliekal ${ }^{b}$ \\ ${ }^{a}$ PhD, Former Director General, The Catholic Health Association of India (CHAI), India. \\ ${ }^{\mathrm{b}} \mathrm{PhD}$, The Catholic Health Association of India (CHAI), India.
}

\begin{abstract}
All women need access to antenatal care in pregnancy, skilled care during childbirth, and care and support in the weeks after childbirth. This discussion tries to look into the life context of maternal and child health, and the health scenario of women/girl children in general in India from the perspective of Human Rights. Currently, most of the public and private health experts and organizations do not talk and act on the human rights perspective of health service delivery. Reversely, only a very few rightsbased organizations advocate directly the right to health for the marginalized. Within the framework of a rights-based approach, the right to (Maternal) Health on practical terms means "Availability, Accessibility, Acceptability and Quality." Concluding, in the background of the Catholic Health Association of India ( $\mathrm{CHAl}$ ), the discussion also focuses on how the nun nurses play their role as "Community Health Enablers" to improve the situation.
\end{abstract}

\section{Introduction}

All women need access to antenatal care in pregnancy, skilled care during childbirth, and care and support in the weeks after childbirth. In spite of the committed efforts by WHO, the State Parties and other stakeholders, the preventable maternal and infant/children mortality is unacceptably high across the developing countries. Only $51 \%$ of women in low-income countries benefit from skilled care during childbirth. ${ }^{1}$

This discussion tries to look into the context of maternal, and child and female health in India in general from the perspective of Human Rights. Currently, most of the public and private health experts and organizations do not talk and act on the human rights perspective of health service delivery. Reversely, only a very few rights-based organizations advocate directly the right to health for the marginalized.

The present discussion on this discriminating life context includes inadequate maternal and child health services, obstetrics abuse, child/early marriage, epidemic of sex selection and abysmal child sex ratio, malnutrition, HIV, TB, disability, social determinants of health, etc. Also, we take a brief look at the negative impact of climate change and environmental pollution, exploitation of women in surrogacy, maternal mental health, and so on. 
As Christian teaching and various international treaties emphasize, human rights are universal, inviolable and inalienable. Within the framework of a rights-based approach, the right to (maternal) health on practical terms means "Availability, Accessibility, Acceptability, and Quality."2 It also means participation and inclusion, equality and non-discrimination, and accountability from the part of the duty bearers (responsible parties), especially the government which has to respect, protect, and fulfill its obligations with respect to the right to health. ${ }^{3}$ Concluding, in the context of the Catholic Health Association of India (CHAI), the discussion also focuses on how nun nurses play their role as "Community Health Enablers" to improve the situation.

\section{Maternal and Child Health: Indian}

\section{Context}

Mothers and children not only constitute a large group, but they are also the most vulnerable in a developing country like India. Women of childbearing age (15-44years) constitute $22.2 \%$ and children under 15 years of age about $35.3 \%$ of the total population, and together they constitute $57.5 \%$ of the population. ${ }^{5}$

According to the latest report of India's Sample Registration System (SRS), the maternal mortality ratio (MMR), in the period $2011-13$ has declined to 167 per 100,000 live births from 212 in
2007. ${ }^{6,8}$ The advance is largely due to key government interventions such as the Janani Shishu Suraksha Karyakaram (which encompasses free maternity services for women and children, a nationwide scale-up of emergency referral systems and maternal death audits, and improvements in the governance and management of health services at all levels) and other schemes and measures. ${ }^{6,78}$

The primary causes of maternal deaths are hemorrhage (mostly bleeding after childbirth), hypertension during pregnancy (pre-eclampsia and eclampsia), sepsis or infections, and indirect causes mostly due to complications caused by pre-existing medical conditions and pregnancy. ${ }^{47}$ Apart from these, the other determinants, such as, early marriage and child bearing, low literacy, economic constraints, and cultural misconceptions may also influence maternal mortality. The main causes of infant mortality in India are perinatal conditions, respiratory infections, diarrhoeal diseases, other infectious and parasitic diseases, and congenital anomalies. $^{52}$

Various steps taken by India have reduced maternal and infant mortality (Figure 1). The advance is largely due to key government interventions. Programs like the Janani Suraksha Yojana, that pays pregnant women to give birth in health facilities and health workers for bringing them in, have pushed up institutional deliveries from $40 \%$ to about $80 \% .^{11}$

Lal Mohan, a daily wage labourer, has no clue what took his wife's life. Sarita Devi, 25, was expecting her third child and was on her way to a good hospital at Bhagalpur district in Bihar. "She was normal all through the nine months of pregnancy," he says. "When labour pains began, we took her to a community health centre (CHC), $15 \mathrm{~km}$ from our house in the Godda district in Jharkhand. At around $11 \mathrm{pm}$, doctors advised us to take her to Sadar Hospital, $20 \mathrm{~km}$ from the CHC. Here again, doctors referred her to Jawaharlal Nehru Medical College and Hospital in Bhagalpur, another $70 \mathrm{~km}$ away." She passed away on the way to hospital. All safe motherhood programmes of the government are focused on institutional deliveries, but health centres are in disarray. ${ }^{4}$

Nov 2016. Christian Journal for Global Health, 3(2): 91-106. 
Figure 1. Key Steps Taken by the Indian Government to Reduce Maternal and Infant Mortality

In a written reply to Lok Sabha by Shri J P Nadda, the Union Minister for Health and Family Welfare, Govt. of India, highlighted the following key steps taken by the Government of India to accelerate the pace of decline in maternal and infant mortality ${ }^{6,8}$ :

- Promotion of institutional deliveries through Janani Suraksha Yojana (JSY)

- Janani Shishu Suraksha Karyakaram (JSSK) Operationalization of Sub-Centers, Primary Health Centers, Community Health Centers, and District Hospitals for providing 24x7 basic and comprehensive obstetric care, neonatal, infant, and child care services

- Mother and Child Protection Card in collaboration with the Ministry of Women and Child Development to monitor service delivery for mothers and children

- Mother and Child Tracking System

- Identifying the severely anaemic cases of pregnant women at sub centres and PHCs for their timely management

- Maternal Death Review (MDR)

- Establishing Maternal and Child Health $(\mathrm{MCH})$ Wings at high caseload facilities

- IFA supplementation programme

- Capacity building of health care providers and setting up of Skill Labs

- Prevention of Post Partum Hemorrhage (PPH) through Community-based advance distribution of Misoprostol by ASHAs/ANMs for high home delivery districts

- Emphasis on facility-based newborn care, i.e., Special New Born Care Units (SNCUs), Newborn Stabilization Units (NBSUs), and Newborn Care Corners (NBCCs) at different levels to reduce child morbidity and mortality

- Launch of India Newborn Action Plan (INAP) with an aim to reduce neonatal mortality and stillbirths to single digit by 2030

- Vitamin $\mathrm{K}$ injection at birth, antenatal corticosteroids for preterm labour, kangaroo mother care and injection gentamicin to young infants in cases of suspected sepsis to reduce newborn mortality

- Diagnosis \& management of Gestational Diabetes Mellitus and Hypothyroidism during pregnancy to reduce maternal mortality and morbidity

- De-worming during pregnancy, Maternal Near Miss Review, Screening for Syphilis during pregnancy, and Dakshata guidelines for strengthening intra-partum care

- Home-based newborn care through ASHAs to improve newborn practices at the community level, and early detection and referral of sick, new-born babies

- Integrated Action Plan for Pneumonia and Diarrhoea (IAPPD) launched in four states with highest infant mortality (UP, MP, Bihar, and Rajasthan)

- Nutritional Rehabilitation Centres (NRCs) for management of severe acute malnutrition in children

- Promotion of appropriate Infant and Young Child Feeding practices

- Village Health and Nutrition Days in rural areas

- Universal Immunization Programme (UIP) to protect children against seven vaccine preventable diseases

- Mission Indradhanush has been launched in 201 high focus districts to fully immunise more than 8.9 million children

- Rashtriya Bal Swasthya Karyakram (RBSK) for health screening and early intervention services to all the children in the age group of 0-18 years, etc

However, these measures did not result in a proportionate reduction of maternal mortality in the country. As per the World Health Statistics (WHS) 2016, the MMR of India is $174 .{ }^{47}$ Taking this WHS 2016 estimate and a birth cohort of around 26 million per year in India into consideration, one can reasonably estimate that nearly 45,000 women die due to childbirth-related causes every year in India. That means nearly five women die every hour in India from complications developed during childbirth with heavy blood loss caused by hemorrhage being a major factor. ${ }^{48}$
According to the Sample Registration System (SRS) 2013, an estimated 1.26 million children under the age of five die in India every year, i.e., nearly 3,500 children under 5 die in India every day. The under-five mortality rate (U5MR) is 49 per 1000 live births (with IMR at 40 - children dying within one year of birth). Fifty-seven per cent of under-five deaths occur in the neonatal period, which is within the first 28 days of life, [i.e., 718,200 newborns die within the first four weeks of birth every year in the country]. The major causes being prematurity and low birth-weight, neonatal 
infections, birth asphyxia, and birth trauma. The major causes of under-five deaths in post-neonatal period are pneumonia and diarrhea. ${ }^{9}$ India has the highest number of child deaths in the world, with an estimated 1.2 million deaths in $2015-20$ per cent of the 5.9 million global deaths. ${ }^{10}$

\section{Obstetric Violence}

The fact is that obstetric abuse is not limited to remote villages or distant towns, it happens quite often in big cities as well. There are instances where the pregnant women were forced to deliver on the floor even though beds were available at the public primary health centres as the attendants reportedly did not want to deal with soiled sheets. Pregnant women are beaten up badly and, worst of all, the doctors feel it was justified.

Women face varying degrees of obstetric violence in most settings. But the worst is the treatment meted out in government hospitals to the poor and most vulnerable population, people who cannot stake a claim to their rights and who do not know their entitlements. It is made worse by a culture of impunity, where health providers know they will get away with it. ${ }^{11}$

A study published in June 2015 which analyzed 65 studies from 34 countries, including India, categorized the abuse into seven domains: physical abuse (e.g., slapping or pinching); sexual abuse; verbal abuse such as harsh or rude language; stigma and discrimination based on age, ethnicity, socio-economic status, or medical conditions; and loss of autonomy. ${ }^{11}$

There exists a distinct class bias towards the vulnerable women from socially and economically excluded communities/families in labor rooms. While the doctors are being extremely decent with patients in their private practice, the same health professionals proceed to shout and use crude language to abuse their patients in government hospitals. Commenting on the untold obstetric abuse, the Madhya Pradesh High Court in one of its judgments had to state the obvious — "a woman's right to survive pregnancy and childbirth is a fundamental right."11

\section{Child/Early Marriage - a Rights \\ Violation and a Primary Cause for}

\section{Unacceptable levels of IMR and MMR}

Child marriage is a violation of child rights and has a negative impact on physical growth, health, mental and emotional development, and education opportunities. It also affects society as a whole since child marriage reinforces a cycle of poverty and perpetuates gender discrimination, illiteracy, and malnutrition as well as high infant and maternal mortality rates. ${ }^{12}$ In India, almost half of all girls between 20 and 24 years marry before the legal age of 18 years. They become pregnant as adolescents. One in six girls begins childbearing between the ages of 15 and 19 years. Early pregnancy increases the risk of delivery complications and maternal and child mortality. The Infant Mortality Rate is 76 per cent for women aged less than 20 years, compared with 50 per cent for women aged 20-29 years. ${ }^{12}$

\section{Epidemic of Sex Selection and Abysmal Child-Sex Ratio}

A revealing cross-cutting fact running through data about children perhaps is the neglect of and discrimination against the girl-child - be it in mortality, morbidity, and nutrition - on account of misguided and unacceptable socio-economiccultural-religious factors. In spite of the much trumpeted economic prosperity in the country, the epidemic of sex selection is still on the rise due to male child preference on account of socialeconomic-cultural-religious factors. The decline of child-sex ratio (age group of 0-6 years) is sharper, recording a decline from 945 girls for 1000 boys in 1991 to 914 in 2011. ${ }^{13}$ India's declining child-sexratio indicates that girls are increasingly being aborted, killed (infanticide), or otherwise dying due to gender biased neglect. More than 50 million 
women have been systematically exterminated from India's population in three generations, through the gender-specific infliction of violence in various forms, such as female feticide through forced abortions, female infanticides, dowry murders, and honor killings. ${ }^{14} \mathrm{~A}$ bride was murdered every hour over dowry demands in 2010, according to India's National Crime Records Bureau. ${ }^{15}$ According to

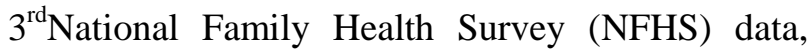
$56 \%$ adolescent girls (15-19 years) are malnourished and anemic, as compared to $30 \%$ adolescent boys. ${ }^{16}$

\section{Adverse Impact of Climate Change and Environmental Risks}

Evidence has shown that climate change will affect the distribution and quality of India's natural resources, which will ultimately threaten the livelihoods of the most poor and marginalized population, especially those engaged in agriculture and its allied sectors. Among the marginalized population, the adverse impact of climate change more greatly affects women and girls, especially in rural areas, excluding them from opportunities like education and equal participation in development. ${ }^{17}$

Indoor and outdoor air pollution together cause about one-fifth of the global mortality from stroke and ischemic heart disease, and more than one-third of deaths from chronic obstructive pulmonary disease. ${ }^{18}$ Indoor air pollution causes significant global mortality and morbidity among women and children below 5 years of age. They are regularly exposed to high levels of indoor air pollution in cramped rooms - exposed to use of biomass fuels, including wood, animal dung, or crop residues, that produce particulates, carbon monoxide, and other indoor pollutants.

Add to this the uncontrolled use of artificial manure and pesticide, adulteration and poisoning of the food thus produced pose serious health risks, especially to children. This brings into context, the relevance of the recent discussions from various quarters on not just the right to food, but the right to good food for all, which is also a matter of equity.

\section{HIV, TB and Gender Discrimination}

The total number of People Living with HIV (PLHIV) in India is estimated at 2.1 million in 2015 as compared with 2.2 million in 2007. Two-fifths (40.5\%) of total HIV infections are among females, while children ( $<15$ years) account for $6.54 \% .^{19}$ When compared to men affected/infected with HIV/AIDS, women and girl children suffer more from the negative social (education, family, and institutional care), economic, psychological/ emotional (stigmatization and discrimination), health (nutrition), and medical (life prolonging drugs) impact of HIV/AIDS. Disclosure of women's HIV status is likely to cause abuse or abandonment by their families and loss of their rights to children and property. ${ }^{20}$

According to the 2014 WHO, Global Tuberculosis Report, India has the highest burden of tuberculosis, with an estimated 2.16 million cases out of a global incidence of 9 million. Despite its prevalence, the stigma surrounding tuberculosis is such that patients, especially women, often delay or deny themselves treatment even after diagnosis. The stigma around the disease is so strong that women detected with or suspected of having tuberculosis have been abandoned or even ostracized by their families. ${ }^{21}$ Gender discrimination, in addition to directly affecting vulnerability to $\mathrm{TB}$ and access to $\mathrm{TB}$ services, can deny girls and women access to education, information, and various forms of economic, social, and political participation, that can increase health risk. $^{22}$

\section{People with Disabilities}

A 2004 survey in the state of Orissa found that virtually all of the women and girls with disabilities were beaten at home, 25 per cent of women with intellectual disabilities had been raped, and 6 per cent of women with disabilities had been 
forcibly sterilized. ${ }^{23}$ Girls with disabilities are also less likely to get an education, receive vocational training, or find employment than boys with disabilities or girls without disabilities.

\section{Exploitation of Women in Surrogacy}

Commercial surrogacy, or "Womb for rent", is a growing business in India. In a country like India with an already alarmingly high maternal death rate, the surrogacy business is exploiting poor women, especially the illiterate from rural areas. ${ }^{24}$ Often, a surrogate mother may get treated like a commodity, too, as she may be, against her will, coerced by the family for economic gain. Frequently, women who rent out their wombs in such situations are poor and ignorant, and often have no idea of possible consequences. ${ }^{25}$ In many cases, children "produced" out of surrogacy become "objects/ commodities" of custody disputes. Often, the child with disability born out of surrogacy is treated like a damaged commodity to be rejected.

Apart from psychological stress, depersonalization and commoditization of women as surrogate mothers, surrogacy may ultimately shatter the traditional (Christian) concept of motherhood.

On the other side of the spectrum, childless couples, especially childless women, due to superstitious beliefs, also face a certain degree of social rejection; for instance, the presence of a childless couple is considered a bad omen, especially the woman.

\section{Maternal and Child/Adolescent Mental Health}

Mental health problems are a key determinant of maternal and child mortality and morbidity, but are not currently recognized in existing initiatives to promote maternal health, and improve sexual and reproductive health and child health. ${ }^{26}$ Cases of perinatal depression are on the rise among young mothers. ${ }^{27}$ The prevalence of antenatal depression reported in India ranged between $9.2 \%$ and $16.2 \%{ }^{28}$ The issue of maternal mental health apart, the prevalence rate of child and adolescent psychiatric disorders in the country is on the rise. As per NFHS-3, in 2005-06, 22\% of adolescents (14-18 yrs) had a mental or behavioral problem, and depression was on the rise. ${ }^{29} 53.22 \%$ of children reported to have faced some form of sexual abuse. ${ }^{30}$ In sum, maternal and child/adolescent mental health — with a treatment gap of $90 \%$ - is indeed a human rights issue. ${ }^{31}$

\section{Gender differences in Social-Economic- Biological Determinants of Health and}

\section{IIIness}

Health and well-being depends not merely on curative medical care, but on one's access and capacity to afford social determinants of health, such as, food, water, shelter, sanitation, education, and other basic needs. Any health-care reforms have to be placed within a national effort to provide these social determinants on an equitable and universal basis. ${ }^{32}$

In the context of maternal and child mortality, one has to take note that in spite of so much talk on economic growth, as per 2011 Census, the female literacy rate in the country was only $65.46 \%$ as compared to an $80 \%$ male literacy rate. ${ }^{33}$ The school dropout rate amongst adolescent girls was a high $63.5 \% .^{13}$ Health and education are closely interrelated.

Literacy not only increases women's selfconfidence but also makes them more exposed to information thereby altering the way others respond to them. Female literacy improves the chances that women will obtain meaningful employment, reduces their demand for children and improves healthseeking behaviour, makes them aware of nutritional requirements - all these combined improve the chances of survival of both - the mother and the baby. ${ }^{34}$

The lower social status of women influences how society responds when they are affected by stigmatizing illnesses, such as HIV/AIDS, leprosy, 
tuberculosis, and mental illness. While both men and women suffer considerable discrimination from society, women are more marginalized by these health problems. ${ }^{35}$ The situation further severely worsens when they are from the socially and economically excluded communities.

Moreover, women, especially in the developing countries, are engaged in reproductive household labour (food preparation, child birth, child rearing, water and fuel collection, shopping, housekeeping, and family health care, care of livestock, kitchen garden, etc.), which are often unaccounted/invisible and considered voluntary. ${ }^{35}$

The biological determinants of health and illness, such as, differential genetic vulnerability to illness, reproductive and hormonal factors, and differences in physiological characteristics during the lifecycle, call for a differential approach to female health issues. ${ }^{35}$

\section{Maternal and Child Health - From Human Rights Perspective}

Maternal health is a human rights issue that has implications for the rights to life, health, equality, nondiscrimination, privacy, freedom from cruel or degrading treatment, and equitable distribution of the benefits of scientific progress, among others. ${ }^{36}$ The Indian health context of maternal and child health brings to the fore, the urgent need of assessing it from the human rights perspective that ". . . every woman, every newborn, everywhere has the right to good quality care. . Good maternal health is a human right, as well as a pre-condition and a determinant of newborn, child, and adolescent health, and of sustainable development more generally." ${ }^{, 51}$

It is evident that the high unacceptable MMR and IMR is a question of equity, be it in India or any other developing country. The lowest socioeconomic strata in India, especially women and children, are grossly deprived of health care facilities leading to poor health outcomes as accessibility to basic health care depends on the socio-economic status of an individual. They are deprived of essential determinants of health, such as safe and secure shelter, safe water supply and sanitation, environmental health and hygiene, and access to food. The untreated ailments are higher in rural areas than in urban areas, among females than males, and the socially and economically excluded dalit and tribal communities than among the nondalits and non-tribals. ${ }^{37}$

From the perspective of human rights, women are entitled to certain rights simply by being human. This means, as the various international treaties on human rights and Christian teaching emphasize, each human person, endowed with intelligence and free will, has rights and duties that are universal and inviolable, and, therefore, altogether inalienable. Each human person "has the right to bodily integrity and to the means necessary for the proper development of life, particularly food, clothing, shelter, medical care, rest, and, finally, the necessary social services." 38

The UN Declaration on Human Rights (Article 25.1) states:

Everyone has the right to a standard of living adequate for the health and well-being of himself and of his family, including food, clothing, housing and medical care and necessary social services, and the right to security in the event of unemployment, sickness, disability, widowhood, old age or other lack of livelihood in circumstances beyond his control. ${ }^{39}$

Art. 12(1) of the International Covenant on Economic, Social and Cultural Rights (ICESCR), ratified by India in 1979, recognizes the right of everyone to the enjoyment of the highest attainable standard of physical and mental health. This includes the State's responsibility to take measures towards the reduction of the stillbirth-rate and of infant mortality, and for the healthy development of the child, etc. "Health is a fundamental human right indispensable for the exercise of other human rights. Every human being is entitled to the enjoyment of the highest attainable standard of 
health conducive to living a life in dignity."2 Additionally, the right to health is recognized, inter alia, in article 5 (e) (iv) of the International Convention on the Elimination of All Forms of Racial Discrimination of 1965, in articles 11.1 (f) (ratified by India in 1968) and 12 of the Convention on the Elimination of All Forms of Discrimination against Women of 1979 (ratified by India in 1993) and in article 24 of the Convention on the Rights of the Child of 1989 (ratified by India in 1992).

The components of the highest attainable standard of health are: Availability, Accessibility, Acceptability and Quality. ${ }^{2}$ These components reiterate women's rights from the perspective of maternal and child health/safe motherhood to scientifically and medically appropriate (quality) healthcare; effective functioning public health and health care facilities, goods, services, and programs in sufficient quantity (availability); accessibility without any discrimination of affordable (economic) physical facilities and services, ethically and culturally appropriate, sensitive to age and gender (acceptability). Each woman is also entitled to the required information needed to make an educated decision. ${ }^{2}$

Woman's right to health also implies, inherently, the underlying principles of participation and inclusion, equality and non-discrimination, accountability and capacity development of duty bearers (responsible parties) in relation to health (policy makers, hospital managers, health professionals, inspectors, and parliamentarians, among others) to meet their obligations and of rights-holders (women and children) to claim their rights. The accountability of the duty bearer implies categorically that the State and the others concerned must respect a woman's right to health, including safe motherhood (without interfering directly or indirectly). Duty bearers have the obligation to protect it by taking measures that prevent third parties, including her own family, community, religion, private and public health facilities, health personnel under whose care they are entrusted, from interfering in the exercise of her rights. Duty bearers have the obligation to fulfill women's and children's right to health by adopting appropriate legislative, administrative, budgetary, judicial, promotional, and other measures to fully realize the right to health. ${ }^{2}$

It is true that in India, government programs and various interventions under the National Health Mission have brought down maternal and infant mortality. There has been a remarkable increase in institutional deliveries. However, this surge in institutional deliveries does not necessarily mean a proportionate reduction in maternal and infant mortality. For this, one needs to ensure a proportionate increase in investment in quality public health facilities and human resources, affordable and accessible, especially to the socially and economically marginalized. This will significantly contribute towards India's achieving Universal Health Coverage / SDG3: "Ensure healthy lives and promote well-being for all at all ages" leaving no one behind.

Mere technological advancement, increase in facilities like emergency obstetric care (EmOC) and skilled birth attendants, without them being equitably and available to rural and poorer women, may in reality, only mask poor quality care. This may be all the more true where birth facilities lack basic resources such as water, sanitation, and electricity. "It is unethical to encourage women to give birth in places with low facility capability, no referral mechanism, with unskilled providers, or where content of care is not evidence-based. .."49

As the authors of the latest Lancet Series on Maternal Health point out, two extreme situations of "too little, too late" (TLTL) and "too much, too soon (TMTS)" exist on the continuum of maternal health care. TLTL, associated with high maternal mortality and morbidity, depicts inadequate resources, low evidence-based standards, or care withheld or unavailable until too late to help. TMTS represents over-medicalization of normal antenatal, intrapartum, and postnatal care, which may eventually cause harm and increase health costs. Often, TMTS results in disrespect and abuse 
of maternal and child health services. For instance, on the one hand, lack of timely facility for Caesarean section, a globally recognized maternal healthcare indicator and, on the other, unnecessary use of the same for non-medical indications, portray TLTL and TMTS, respectively. ${ }^{50}$

The State as a duty bearer in India was not consistent with its draft National Health Policy 2015 where the health budget is concerned. The draft National Health Policy also envisages raising progressively the public health expenditure to 2.5 percent of the GDP. However, the total expenditure for health is only 1.62 percent of the whole budget, out of which the National Health Mission has a share of less than one percent. Here too, the government is deviating from the core strategies of the National Health Mission as there is no increase in allocation for the health sector. ${ }^{40}$

The question here is also one of net utilization, whether even this meager government expenditure on health actually reaches the real beneficiary, thereby effectively increasing the universal health coverage, benefitting the neediest, mostly residing in the most remote areas. "The main concern is that out of the total government spending on the health sector, only 20 per cent of poor people are able to get the true benefit of healthcare facilities." 41

The health systems in the country have to focus not only on the reduction of maternal mortality but also on maternal morbidities, resulting from poor quality of maternity care. Respectful care at birth is very important. ${ }^{42}$ The attempts to "normalize" labor room abuse cannot be accepted but must be fought against by all means, without which all other attempts to improve maternal and newborn health care services will become futile. In this process of advocating quality maternal and child health services, not only women but equally also men need to be involved. Men can play an important role in changing attitudes that restrict women's access to health care and economic opportunities and in reducing violence against women. ${ }^{43}$

\section{CHAl - Growth of an Organization}

\section{from a Welfare and Need-Based}

\section{Approach to a Rights-Based Approach}

in Healthcare Delivery

Founded in 1943 by Sr. Dr. Mary Glowrey an Australian medic and Catholic nun, the Catholic Health Association of India (CHAI) is one of the largest not-for-profit faith-based healthcare networks. ${ }^{44}$ From the late 1980 s, akin to the historical shift in the development sector from welfare to need to rights-based approaches with the UN Declaration on the Right to Development in 1986, CHAI gradually started shifting its focus to one of rights-based interventions. It started to undertake community health projects, with emphasis on primary health care to the marginalized at their doorsteps. The Declaration of Alma-Ata 1978, declaring primary healthcare as the first element of a continuing healthcare process, was also an impetus to this shift to community health.

CHAI has a membership base of over 3,500 healthcare institutions to date. $90 \%$ of them are headed by women religious; $80 \%$ of them are located in remote medically underserved rural areas, operating under 11 regional units across the country. Under the CHAI network today, there are, altogether, over 2,300 health centers and 627 hospitals spread across all states - with a total of over 50,000 beds. CHAI member institutions (MIs) extend medical care to over 21 million patients in a year with a special emphasis on maternal and child health. It has a fulltime dedicated volunteer core of over 600 nun-doctors; 25,000 nun-nurses; 10,000 plus nun-paraprofessionals and over 15,000 nun / priest social workers, along with over 100,000 lay employees/collaborators.

CHAI MIs maintain rehabilitation, care, and support centers for adults and children living with HIV, children/youth with disabilities, elderly and terminally ill, mentally ill, etc. CHAI has 218 social service societies across the country as its members, advocating the health rights of the 
marginalized and socially excluded communities, with special emphasis on the health rights of women and children. CHAI also implements 20 major community health projects across India in collaboration with its member institutions (MIs), other NGOs, and the government.

\section{Some of CHAl Community Health}

\section{Projects in Maternal and Child Health}

Under its Community Health Service Project, supported by Misereor, during the last one year alone, CHAI has trained and mentored 462 women community health volunteers/activists of 390 villages covering 9 States and involving 60 member institutions. They are mainly involved in facilitating antenatal-intranatal-postnatal services, ensuring quality services through public health facilities and programs for pregnant women/ mothers and newborns.

Supported by Kindermissionswerk Germany, CHAI has initiated a pilot project "Promoting $\mathrm{MCH}$ through Mothers' Clubs" in 7 states partnering with 10 member hospitals. The project provides comprehensive maternal healthcare (antenatal/intranatal/postnatal care, nutrition support, childcare, mothers' club for awareness creation, etc.) to 1000 pregnant women of BPL families in rural and remote areas, over a period of 1000 days - from pregnancy to the child's $2^{\text {nd }}$ birthday. Mothers' Clubs are formed to create awareness among pregnant women/young mothers about their rights and entitlements along with the health issues pertinent to them and their newborns.

With support from World Diabetes Foundation (WDF) - Denmark and Medtronic - USA, CHAI implements a prevention and control of diabetes project, covering 5 districts of Uttar Pradesh and one district in Rajasthan, with special emphasis on pregnant women.

In collaboration with Global Fund, The Union, and the Revised National Tuberculosis Control Program (RNTCP), since 2010, CHAI has been implementing Project Axshya ("Civil Society
Engagement in prevention \& control of TB"), involving over 1600 community health volunteers (Axshya Mitras) of 384 NGOs, in 96 districts, including 9 cities, across 10 states. Within 24 months of the project's $2^{\text {nd }}$ phase, Axshya Mitras visited 2,390,510 households creating awareness about TB, actively identifying people with symptoms, and linking them to diagnostic and treatment services under RNTCP. The project resulted in 256,411 people getting screened and tested. Of these, 22,134 (8.63\%) tested positive (including over 8,900 women), and 21,726 were put on treatment. The project established TB Forums in all the target districts, constituted of volunteers who facilitate medical-social-economic support for TB patients and their families, especially from the government.

CHAI, with support from various donors, especially Liliane Foundation (LF), provides education, health, and rehabilitation support annually for over 10,000 differently-abled children/young adults, mainly in partnership with 116 Partner Organizations (POs) spread across 8 states of India. The project provides support for comprehensive rights-based assistance to persons with disabilities, belonging to marginalized families.

CHAI MIs continue to administer 90 Holistic Care Centres (HCCs) supporting People Living with HIV (PLHIV) - formerly Community Care Centres (CCCs), in spite of the fact that the government/NACO stopped supporting them in April 2013, as part of mainstreaming HIV/AIDS into the general health system but without a proper transition plan. Supported by Misereor Germany, 30 of these HCCs alone provided care and support for 88,341 PLHIV during a period of two years. Over 40 MIs provide nutrition and education support to over 5,000 orphan and vulnerable children (OVCs), infected/affected by HIV/AIDS.

During the last 5 years alone, CHAI trained over 16,990 health professionals, frontline health workers, allied professionals, social workers, and 
community health volunteers on various health issues, including maternal and child health. For instance, in partnership with UNICEF-Andhra Pradesh, CHAI implemented a pilot project for enhancing quality newborn care and extending routine immunization coverage. The aim was to complement the government's efforts to reduce infant mortality (IMR) through intensive Social and Behaviour Change Communication (SBCC) trainings to 177 health educators and 600 Accredited Social Health Activists (ASHAs) of two high-priority districts.

\section{Way Forward - The Indian Church's \\ Response}

Today's health scenario of the country is marked by the growing commercialization of healthcare and the increasing tendency of exploitation in the midst of sickness and suffering; growing legal requirements of standards for quality care and patient safety; increasing erosion of ethical care, holistic health, and spirituality of healthcare; double burden of communicable and noncommunicable diseases, etc. All the more, internally, the Catholic health facilities are ministering in isolation leading to unnecessary duplication and wastage of resources.

These external and internal challenges forced the Catholic Health Association of India and its MIs to initiate a participatory Strategic Planning Process (SPP) in collaboration with the Catholic Bishops Conference of India (CBCI) Office for Healthcare in 2013. The goal of the SPP is to enable the Church's health ministry to reposition itself to meet the emerging challenges and to advocate the right to health (accessible, acceptable, and affordable quality healthcare) for all, especially the marginalized and vulnerable women and children.

Most of the Catholic healthcare facilities and personnel belong to various women religious orders, most of them being CHAI's MIs. Hence, the key to repositioning of Catholic health ministry is to enable them to revisit their health ministry and discern the challenges, rediscover their place and role in the emerging context, and reposition themselves accordingly. The situation also calls upon these orders for a metamorphosis in organization, management, and operations - to transcend the culture of ministering in isolation to work together as part of the larger Church for a better impact in the society, i.e., to become an intercongregational entity.

\section{Nun-Nurses as "Community Health Enablers" - Advocates of the Right to Health}

Taking Action 2020: Repositioning for the Future (resulting from the SPP) from the conceptual level into practice, CHAI currently implements a project "Repositioning of Religious Orders," supported by the Conrad N. Hilton Foundation. In fact, rather than a project, we may have to consider it as a process of aggiornamentospirit of change and open-mindedness to be swept into the healing ministry of the Catholic Church. The process supports measures towards networking and capacity building of religious orders/sisters in order to reposition the health ministry of the Church in today's context.

One of the measures is to facilitate various religious orders to reposition their members as "Community Health Enablers," as grassroots level workers. This means nuns, who are nurses, get involved in local communities, especially as women leaders, in planning, implementation, and monitoring of health care delivery. It means empowering people to be in charge of their own health. The nun-nurses, as community health enablers, must accept people as health resources for their own cause, rather than merely viewing them as sources of pathology and as targets for preventive/ therapeutic services. They must build and nurture caring groups of local community health volunteers.

The paradigm shift in this whole process is that the nun-nurses, instead of waiting for people to come to their health centers, have to go out of their four walls to reach out to people at their door steps. As Pope Francis exhorts, "I prefer a Church which is bruised, hurting and dirty because it has been out 
on the streets, rather than a Church which is unhealthy from being confined and from clinging to its own security." 45 Supporting these nun-nurses in this endeavor, their respective religious orders, in particular, and the Indian Catholic Church, in general, have to refrain from being the "opportunistic" faces of Christ's mercy.

Facilitating this paradigm shift, CHAI is in the process of training nun-nurses, currently managing health centers singlehandedly in remote rural areas. This is so they can not only to reposition themselves as community enablers, but also equip themselves to capacitate and mentor community health volunteers, and provide quality community outreach services, with special emphasis on maternal and child health. This also means to mentor, technically support, and collaborate with the existing frontline health workers, such as accredited social health activists (ASHAs), Anganwadi workers, etc. The nunnurses as community health enablers along with the health volunteers make the women aware of the right to quality maternal and child care. Communitizing maternal and child health, they enable women with information and skills on govt. programs and interventions, to demand and access their rights and entitlements; to organize to fight against mistreatment, abuse, disrespect, and neglect that they face, especially in maternal and child health facilities. Thereby, they complement the country's efforts towards achieving Universal Health Coverage / SDG3: "Ensure healthy lives and promote well-being for all at all ages," leaving no one behind.

The mentoring of caring groups of active community health volunteers means also that these nun-nurses, as community health enablers/activists, have to replicate themselves. They have to enable some of the community health volunteers as community health activists, advocating the rights and entitlements of their respective communities so that eventually the nun-nurses as community health enablers can recede to the background and move to other communities advocating equitable quality health care for all. The aim is to be the visible faces of Christ's compassionate care and healing touch! To be the Christ-inspired positive influence against the growing commercialization of health ministry. ${ }^{46}$

\section{References}

1. WHO. Maternal mortality [Internet]. Fact sheet $\mathrm{N}^{\circ} 348$. Geneva: World Health Organization; [Updated November 2015; cited 2016 Jul 25]. Available from: http://www.who.int/mediacentre/factsheets/fs348/en/

2. UN. CESCR General Comment No. 14: The right to the highest attainable standard of health (Art. 12) [Internet]. Office of the High Commissioner for Human Rights. Geneva: United Nations; [Adopted on 11 May 2000, cited 2016 Jul 25]. Available from: http://www.refworld.org/pdfid/4538838d0.pdf

3. UN. Human rights-based approach to health [Internet]. Office of the High Commissioner for Human Rights. Geneva: United Nations and World Health Organization; [cited 2016 Jul 25]. Available from:

http://www.ohchr.org/Documents/Issues/ESCR/Heal th/HRBA HealthInformationSheet.pdf

4. Pandey K. Delivering safety. Down to earth [Internet]. 2014 April 30; [cited 2016 Jul 25].

Available from: http://www.downtoearth.org.in/coverage/delivering$\underline{\text { safety-44037 }}$

5. Mishra IM. Maternal and child health programme [Internet, PPT in Slideshare.net]. 2015 March; [cited $2016 \mathrm{Jul}$ 25]. Available from: http://www.slideshare.net/INDRAMANIMISHRA/m aternal-and-child-healthprogramme46306252?utm source=slideshow02\&ut $\underline{\mathrm{m}}$ medium=ssemail\&utm campaign $=$ share slidesho $\underline{\mathrm{w} \_ \text {loggedout }}$

6. Press Information Bureau. Achievements under millennium development goals [Internet]. New Delhi: Ministry of Health and Family Welfare, Govt. of India, 2015 July 24; [cited 2016 Jul 25]. Available from:

http://pib.nic.in/newsite/PrintRelease.aspx?relid=123 $\underline{669}$

7. UNICEF India. Maternal health [Internet]. New Delhi: United Nations International Children's Emergency Fund - India; [cited 2016 Jul 25]. Available from: 
http://unicef.in/Whatwedo/1/Maternal-

Health\#sthash.vQi20Z2e.dpuf

8. National Institute of Public Cooperation and Child

Development. An analysis of levels and trends in maternal health and maternal mortality ratio in India [Internet]. New Delhi: 2015 June 16; [cited 2016 Jul 25]. Available from: http://nipccd.nic.in/reports/mhmm.pdf

9. Press Trust of India. 1.26 million children under 5 die In India every year, admits government [Internet]. New Delhi: NDTV. Every Life Counts. 2016 April 26; [cited 2016 Jul 25]. Available from: http://everylifecounts.ndtv.com/1-26-millionchildren-under-5-die-in-india-every-year-admitsgovernment-2506

10. Mascarenhas A. India missed 2015 child mortality target: Lancet report. Indian Express. 2015 September 9; [cited $2016 \mathrm{Jul}$ 25]. Available from: http://indianexpress.com/article/india/indiaothers/india-missed-2015-child-mortality-targetsays-lancet-report/\#sthash.Kbg1ic7F.dpuf

11. Nagarajan R. The labour room bullies. The Times of India. 2015 November 15; [cited 2016 Jul 25]. Available from: http://timesofindia.indiatimes.com/india/The-labourroom-bullies/articleshow/49791192.cms

12. UNICEF India. Child marriage [Internet]. New Delhi: United Nations International Children's Emergency Fund — India; [cited 2016 Jul 25]. Available from: http://unicef.in/Whatwedo/30/ChildMarriage

13. Social Statistics Division. Children in India 2012 [Internet]. New Delhi: Central Statistics Office, Ministry of statistics and Programme Implementation, Government of India, 2012 September; [cited $2016 \mathrm{Jul}$ 25]. Available from: http://mospi.nic.in/Mospi_New/upload/Children_in_ India 2012.pdf

14. Banerji R. Female genocide in India and the 50 million missing campaign [Internet]. Intersections: Gender and Sexuality in Asia and the Pacific. 2009 Oct 22; [cited 2016 Jul 25]. Available from:

http://intersections.anu.edu.au/issue22/banerji.htm

15. Baker KJM. Sex selective abortion isn't the real reason why India is the worst country for women. JAZEBEL. 2012 June 14; [cited 2016 Jul 25]. Available from: http://jezebel.com/5918361/sex- selective-abortion-isnt-the-real-reason-why-india-isthe-worst-country-for-women

16. Press Information Bureau. Adolescent anaemia [Internet].New Delhi: Ministry of Health and Family Welfare, Govt. of India, 2013 March 2014; [cited $2016 \mathrm{Jul}$ 25]. Available from: http://pib.nic.in/newsite/PrintRelease.aspx?relid=934 $\underline{67}$

17. CLRA and Oxfam India. The human impact of climate change in India [Booklet]. New Delhi: Centre for Legislative Research and Advocacy \& Oxfam India [cited $2016 \mathrm{Jul}$ 25]. Available from: http://www.clraindia.org/admin/gallery/documents/0 30320161159320Human\%20Impact $\% 20$ of $\% 20$ Climate $\% 20$ Change $\% 20$ in\%20India\%20(Booklet).pdf

18. WHO. Health and the environment: addressing the health impact of air pollution [Internet]. Geneva: Geneva: Sixty-Eighth World Health Assembly (WHA), World Health Organization, 2015 April 10; [cited 2016 Jul 25]. Available from: http://apps.who.int/gb/ebwha/pdf_files/WHA68/A68 _18-en.pdf

19. NACO. India HIV estimations 2015: technical report [Internet]. New Delhi: National AIDS Control Organisation and National Institute of Medical Statistics, ICMR, Ministry of Health \& Family Welfare, Government of India; [cited 2016 Oct 15]. Available from:

http://indiahivinfo.naco.gov.in/naco/resource/indiahiv-estimations-2015-technical-report

20. UN. The HIV/AIDS pandemic and its gender implications: report of the expert group meeting [Internet]. New York: Division for the Advancement of Women Department for Economic and Social Affairs (DESA), United Nations, 2000 November 13-17; [cited 2016 Jul 25]. Available from: www.un.org/womenwatch/daw/csw/hivaids/report.p df

21. Rao M. The gendered delay in the diagnosis and treatment of tuberculosis patients in India. The Karavan. A Journal of Politics and Culture. 2015 September 23; [cited 2016 Jul 25]. Available from: http://www.caravanmagazine.in/vantage/gendereddelay-diagnosing-tuberculosis-patients

22. WHO. A human rights approach to TB: stop TB guidelines for social mobilization [Internet]. 2001. Geneva: World Health Organization, 2001; [cited $2016 \mathrm{Jul}$ 25]. Available from: 
http://www.who.int/hhr/information/A\%20Human\% 20Rights\%20Approach\%20to\%20Tuberculosis.pdf

23. UN. Some facts about persons with disabilities. Enable. New York: United Nations, 2006 August 1425; [cited 2016 Jul 25]. Available from: http://www.un.org/disabilities/convention/pdfs/factsh eet.pdf

24. Anu Kumar P, Inder D, Sharma N. Surrogacy and women's right to health in India: Issues and perspective. Ind J Pub Heal. 2013 July 15;57(2): 6570; [cited $2016 \mathrm{Jul} 25$ ]. Available from: http://www.ijph.in/article.asp?issn=0019557X; year $=2013 ;$ volume $=57 ;$ issue $=2 ;$ spage $=65 ;$ epag $\mathrm{e}=70$; aulast $=\mathrm{Anu} \% 2 \mathrm{C}$

25. Aravamudan G. Burden of surrogacy. The Hindu. 2015 May 30; [cited 2016 Jul 25]. Available from: http://www.thehindu.com/features/magazine/burdenof-surrogacy/article7264366.ece

26. WHO. Maternal mental health and child survival, health and development in resource-constrained settings: essential for achieving the Millennium Development Goals [Internet]. Geneva: World Health Organization; [cited 2016 Jul 25]. Available from:

http://www.biomedcentral.com/content/supplementar y/1752-4458-5-2-S1.PDF

27. Muzik M, Borovska S. Perinatal depression: implications for child mental health. Ment Health Fam Med. 2010 December;7(4):239-47; [cited 2016 Jul 25]. Available from: http://www.ncbi.nlm.nih.gov/pmc/articles/PMC3083 253/

28. Baron EC, Hanlon C, Mall S, Honikman S, Breuer E, Kathree T, et al. Maternal mental health in primary care in five low- and middle-income countries: a situational analysis. BMC Health Services Research. 2016;16(53); [cited 2016 Oct 14]. Available from: https://bmchealthservres.biomedcentral.com/articles/ 10.1186/s12913-016-1291-z

29. NCPCR. Status of children in 14-18 years: review of policy, programme and legislative framework [Internet]. New Delhi: National Commission for Protection of Child Rights, The Ministry of Health \& Family Affairs, Govt. of India, 2012-2013; [cited 2016 Jul 25]. Available from: http://ncpcr.gov.in/view_file.php?fid=466

30. Ministry of Health \& Family Affairs. Study on child abuse - India [Internet]. New Delhi: Ministry of Health \& Family Affairs, Govt. of India, 2007; [cited
2016 Jul 25]. Available from: http://www.indianet.nl/pdf/childabuseIndia.pdf

31. Shastri P C. Promotion and prevention in child mental health. Indian J Psych. 2009 April June;51(2): 88-95; [cited 2016 Jul 25]. Available from: http://www.ncbi.nlm.nih.gov/pmc/articles/PMC2755 $174 /$

32. Narayan R. Universal health care in India: missing core determinants. The Lancet. 2011 January 11;377(9769):883-5; [cited 2016 Oct 15]. Available from:

http://www.thelancet.com/journals/lancet/article/PIIS 0140-6736(10)62045-4/fulltext?rss=yes http://dx.doi.org/10.1016/S0140-6736(10)62045-4

33. Census 2011. Literacy rate of India [Internet]. New Delhi: Office of the Registrar General, Ministry of Home Affairs, Govt. of India; [cited 2016 Jul 25]. Available from: http://www.census2011.co.in/literacy.php

34. Jain G, Bisen V. Female literacy \&its relevance with maternal and infant mortality rates. Int J Manag. 2012 May-August 3(2):65-79. [cited 2016 Jul 25]. Available from: http://www.iaeme.com/MasterAdmin/UploadFolder/ FEMALE\%20LITERACY.pdf

35. Vlassoff C. Gender differences in determinants and consequences of health and illness. J Health Popul Nutr (JHPN). 2007 March; 25(1):47-61.[cited 2016 Jul 25]. Available from: http://www.ncbi.nlm.nih.gov/pmc/articles/PMC3013 263/

36. Taylor R, Hartman K, Guillen PA, Ayala A. Human rights maternal health and human rights: national and global perspectives [Internet]. 2012 Samuel Dash Conference. New Jersey: Human Rights Institute, George Town Law; 2012; [cited 2016 Jul 25].

Available from: https://www.law.georgetown.edu/academics/centersinstitutes/human-rights-institute/events/upload/2012Maternal-Health-and-Human-Rights-OutcomeDocument.pdf

37. Dilip TR. Extent of inequity in access to health care services in India. In: Gangolli L, Duggal R, Shukla A, editors. Review of Health Care in India. Mumbai: Centre for Enquiry into Health and Allied Themes (CEHAT); 2005: 247-68; [cited 2016 Jul 25]. Available from: 
http://www.cehat.org/publications/PDf\%20files/r51. pdf

38. Pope John XXIII. Pacem in Terris. Encyclical. Vatican: Libreria Editrice Vaticana; 1963 April 11: § 9 \& 11; [cited 2016 Jul 25]. Available from: http://w2.vatican.va/content/johnxxiii/en/encyclicals/documents/hf jxxiii_enc_11041963_pacem.html

39. UN. Universal declaration of human rights. New York: General Assembly resolution 217 A, United Nations; 1948 December 10; [cited 2016 Jul 25]. Available from: http://www.un.org/en/universaldeclaration-human-rights/

40. Sharma NC. India's health woes: budget for the National Health Mission remains stagnated at Rs. 19,000 crore. India Today. 2016 March 2; [cited $2016 \mathrm{Jul}$ 25]. Available from:

http://indiatoday.intoday.in/story/indias-health-woesbudget-for-the-national-health-mission-remainsstagnated-at-rs-19-000-crore/1/609824.html

41. DNA. ' 3 a's (availability, affordability, and assurance) must for improving healthcare in India'. Daily News and Analysis (DNA). 2013 September 21; [cited 2016 Jul 25]. Available from: http://www.dnaindia.com/health/1891984/report-3-as-availability-affordability-and-assurance-must-forimproving-healthcare-in-in

42. Khanna R. Understanding maternal health from a gender and rights perspective: a training module for advocates and practitioners. Kancheepuram, Tamil Nadu: CommonHealth; 2013 August; [cited 2016 Jul 25]. Available from:

http://www.sahaj.org.in/uploads/4/5/2/5/45251491/u nderstanding maternal health_from_a gender_and rights_perspective.pdf

43. HealthBridge.ca [Internet]. Gender equality, reproductive, maternal, newborn \&child health [Internet]. Ottawa: HealthBridge, [updated 2016 July 26; cited 2016 July 26]. Available from: http://healthbridge.ca/programs/reproductivematernal-and-child-health

44. For the information below on CHAI, I am indebted to Chai-India.org [Internet]. Secunderabad: The Catholic Health Association of India (CHAI), [updated 2016 July; cited 2016 July 25]. Available from: http://chai-india.org

45. Pope Francis. Evangelii Gaudium. Apostolic Exhortation. Vatican: Libreria Editrice Vaticana;
1963 April 11: § 49; [cited 2016 Jul 25]. Available from:

http://w2.vatican.va/content/francesco/en/apost_exho rtations/documents/papa-francesco esortazioneap_20131124_evangeliigaudium.html\#The joy of the gospel

46. O'Clock GD. Isaiah's Leper [Internet]. New York: iUniverse; 2005: p.24; [cited 2016 Jul 25]. Available from: https://www.google.co.in/search?tbo=p\&tbm=bks\&q =isbn:0595351417

47. WHO. World health statistics 2016: monitoring health for SDGs. Geneva: World Health Organization; [cited 2016 Sep 23]. Available from: http://www.who.int/gho/publications/world_health_s tatistics/2016/en/

48. Press Trust of India (PTI). Five women die every hour in India during childbirth: WHO. Economic Times. 2016 June 16; [cited 2016 Jul 25]. Available from:

http://articles.economictimes.indiatimes.com/201606-16/news/73818480_1_maternal-deaths-childbirthwhs

49. Campbell OMR, Calvert C, Testa A, Strehlow M, Benova L. Keyes E, et al. The scale, scope, coverage, and capability of childbirth care. The Lancet. Sept 2016; 388 (10056): 2193 - 2208. http://dx.doi.org/10.1016/S0140-6736(16)31528-8

50. Miller S, Abalos E, Chamillard M, Clapponi A, Colaci D, Commandé, et al. Beyond too little, too late and too much, too soon: a pathway towards evidence-based, respectful maternity care worldwide. The Lancet. Oct 2016; 388 (10056): 2176-2192. http://dx.doi.org/10.1016/S0140-6736(16)31472-6

51. The Lancet. Maternal health: an executive summary for The Lancet's Series. The Lancet Series. Maternal Health 2016. 2016 September 15; [Cited 2016 Oct 15]. Available from:

http://www.thelancet.com/pb/assets/raw/Lancet/stori es/series/maternal-health-2016/mathealth2016-execsumm.pdf

52. National Health Mission (NHM). Child Health. Ministry of Health and Family Welfare. Govt. of India. Updated on 2015 March 2; [Cited 2016 Nov 1]. Available from: $\underline{\text { http://nrhm.gov.in/nrhm- }}$ components/rmnch-a/child-healthimmunization.html 
Peer Reviewed

Competing Interests: None declared.

Acknowledgements: Rev. Dr. Tomi Thomas presented this paper in 100th German Catholic Convention 2016, held on 28th May 2016, at Leipzig, Germany.

Correspondence: Rev. Dr Tomi Thomas, The Catholic Health Association of India (CHAI), India. directorgeneral@chai-india.org Dr Anto Maliekal, The Catholic Health Association of India (CHAI), India. antoseena@gmail.com

Cite this article as: Thomas T, Maliekal A. Maternal and child health from a human rights perspective: the Indian scenario and nuns as community health enablers. Christian Journal for Global Health (Nov 2016), 3(2):91-106.

(C) Thomas T, Maliekal A. This is an open-access article distributed under the terms of the Creative Commons Attribution License, which permits unrestricted use, distribution, and reproduction in any medium, provided the original author and source are properly cited. To view a copy of the license, visit http://creativecommons.org/licenses/by/4.0/

www.cjgh.org

Nov 2016. Christian Journal for Global Health, 3(2): 91-106. 